\title{
2018 Yılında Uygulanan Sigorta Prim Teşvikleri Üzerine Düşünceler
}

\section{Reflections on Insurance Premium Incentives in 2018}

\author{
Doç. Dr. IIhan Oral ${ }^{1}$
}

Başvuru Tarihi: 25.10.2019

Kabul Tarihi: 30.12.2019

\section{Öz}

İssizlik, günümüzde hem gelişmiş ülkelerin hem de gelişmekte olan ülkelerin en önemli sorunlarından biridir. Teknolojik gelişmelerin iş gücüne olan talebi azaltması ve diğer yandan da çoğalan nüfusun işgücü arzını artırması nedeniyle işsizlik sorununa çözüm bulabilmek çok kolay görünmemektedir. Bu bakımdan işsizlik tüm ülkeler açısından dikkatle takip edilmesi gereken ekonomik sorunların başında gelmektedir.

Devletin işsizlikle mücadelede kullandığı belirli politikalar vardır. Bunlar, aktif ve pasif işgücü piyasası politikalarıdır. Aktif politikalar istihdam yaratmaya yönelikken pasif politikalar da işsizliğin olumsuz sonuçlarını gidermeye yöneliktir. Istihdam artırıcı aktif işgücü piyasası politikalarından biri de işverenlere uygulanan sigorta prim teşvikleridir. Prim teşvikleriyle devlet işverenlerin üzerindeki işçilik maliyetini azaltarak istihdamı artırmayı amaçlamaktadır.

Türkiye'de de aktif işgücü piyasası politikaları kapsamında istihdamı artırmak için çeşitli prim teşvik programları uygulanmaktadır. Bunlar, genç ve kadın sigortalıların işgücüne katılımının sağlanmasına, mesleki ve teknik eğitimin özendirilmesine yönelik sigorta primi işveren hissesi teşviki, işsizlik ödeneği alan işçileri işe alan işverenlere prim teşviki, sigorta primi işveren hissesinde 5 puanlık indirim, engelli istihdamı sigorta primi işveren hissesi teşviki, ar-ge personeli prim teşviki, yatırım teşvik belgesi sahipleri için sigorta primi işveren hissesi desteği gibi teşviklerdir.

Bu çalışmada, Türkiye'de 2018 yll itibariyle uygulanan sigorta prim teşvikleri ele alınarak bu kapsamda uygulanan yeni teşvikler ve daha önce uygulanmakta olan teşvikler incelenmiş, bu uygulamalar arasında bir standardın olmadiğı, birçok farklılık bulunduğu görülmüş ve çözüm önerileri sunulmuştur.

Anahtar Kelimeler: Prim, Teşvik, İndirim

\footnotetext{
${ }^{1}$ Anadolu Üniversitesi İktisat Fakültesi ÇEKO Bölümü, aioral@anadolu.edu.tr, ORCID: 0000000317842581
} 


\section{Abstract}

Unemployment is one of the most important problems of both developed and developing countries. It is not easy to find a solution to the unemployment problem because technological developments reduce the demand for the workforce and the growing population increases the labor supply. In this respect, unemployment is one of the most important economic problems that should be closely monitored for all countries.

There are certain policies that the state has used to combat unemployment. These are active and passive labor market policies. While active policies are aimed at creating employment, passive policies are aimed at eliminating the negative consequences of unemployment. One of the employment-enhancing active labor market policies is the insurance premium incentives to increase employment by reducing labor costs on employers.

Various premium incentive programs are implemented in Turkey to increase employment within the scope of active labor market policies. These include the promotion of employer's share of insurance premium for the participation of young and female insurance holders in the labor force, encouragement of vocational and technical education, premium incentive for employers employing unemployment benefit, 5 percentage point of insurance premium employer These are incentives such as discount, employer's share incentive for employers with disability employment, premium incentive for $R$ \& D staff, insurance premium employer's share support for holders of investment incentive certificates.

This study aims to analyze the current and previous applied insurance premium incentives within the context of incentive policy in Turkey in 2018. As a result, it is seen that there is not a standard and there are many differences between these applications and some suggestions are presented in this context.

Keywords: Premium, Incentives, Inducement

\section{Giriş}

Sosyal sigorta prim oranlarının azaltılması ya da işverenlerce ödenmesi gereken belirli bir kısmının devlet tarafından karşılanması istihdamın teşvik edilmesinde etkili bir araçtır. Bu tür teşvikler aynı zamanda kayıt dışı istihdamın kayıt altına alınmasını da kolaylaştırmaktır. $\mathrm{Bu}$ nedenle son yıllarda işverenlerin pirim ödeme yükümlülügü konusunda önemli teşvikler öngörülmüştür. Bu çalışmada, 5510 sayılı Kanunun 4/1/(a) bendi kapsamında sigortalı çalıştıran özel sektör işverenlerine, kayıtlı sigortalı istihdamının arttırılması, kadınlar, gençler ve engelliler gibi dezavantajlı grupların istihdamının arttırılması, bölgesel, büyük ölçekli yatırımlar ile stratejik yatırımların özendirilmesi, bölgesel gelişmişlik farklılıklarının azaltılmasını sağlamak amacıyla;

- 5510 sayılı Kanunda beş,

- 4447 sayılı İşsizlik Sigortası Kanununda yedi,

- 4857 sayılı İş Kanununda bir, 
- 5746 Araştırma ve Geliştirme Faaliyetlerinin Desteklenmesi Hakkındaki Kanununda bir,

- 5225 sayılı Kültür Yatırımları ve Girişimlerini Teşvik Kanununda bir

olmak üzere başlıca toplam on beş farklı sigorta prim teşviki, desteği ve indirimi ele alınarak değerlendirilecektir.

\section{4/1/(a)'ı Malullük, Yaşlılık ve Ölüm Sigortası Primlerinin İşveren Hissesinden 5 Puanlık İndirim (5510/81/1/(1))}

Özel sektör işverenlerinin yararlandığ bu teşvikin başlama tarihi 01.10.2008'dir. 5510 sayılı Kanunun 81. maddesinin 1. fikrasının (1) bendine göre, özel sektör işverenlerinin ödemeleri gereken malullük, yaşlılık ve ölüm (MYÖ) sigortaları primlerinin işveren hissesinin (\%11) 5 puanlık kısmına isabet eden tutar Hazine tarafından karşılanmaktadır. Bu teşvik, 506 sayılı Kanunun geçici 20. maddesi (5510 sayılı Kanun Geçici m.20) kapsamındaki sandıkların statülerine tabi personel için de uygulanmakla birlikte Kamu idareleri bu teşvikin kapsamı dışında kalmaktadır. Ayrıca, sosyal güvenlik destek primine tabi çalışanlar ile yurtdışında çalışanlar da bu teşvikin kapsamı dışında kalmışlardır. Teşvik, prime esas kazanç üzerinden hesaplanmakta ve sürekli olarak uygulanmaktadır (Güzel vd, 2018, s.304; Gerek ve Oral, 2019, s.194). Teşvikten yararlanabilmek için yerine getirilmesi gereken birtakım "genel şartlar" bulunmaktadır. Bunlar:

- Aylık prim ve hizmet belgesinin yasal süresinde Kuruma verilmiş olması,

- Primlerin yasal süresi içinde ödenmesi,

- Prim, idari para cezası ve bunlara ilişkin gecikme zammı ve cezası borcunun bulunmamas1,

- Borcu varsa, bu borçların yapılandırılmış veya taksitlendirilmiş olması,

- Yapılandırılmış/taksitlendirilmiş borçların zamanında ve düzenli bir şekilde ödenmesine devam edilmesi,

- Kayıt dışı sigortalı çalıştırılmaması ve

- Sahte sigortalı bildiriminde bulunulmamış olunmasıdır.

Sosyal Güvenlik Kurumunun uygulamasına göre, teşvikten yararlanabilmek için işverenlerin sadece kendilerinin değil iş verdikleri alt işverenlerin de Kuruma herhangi bir borcunun bulunmaması gerekmektedir. 5510 sayılı Kanunun 6824 sayılı Kanunla değişik ek 14. maddesinin 1. fikrasina göre, mahkeme kararıyla veya yapılan kontrol ve denetimlerde çalıştırdığı kişileri sigortalı olarak bildirmediği veya bildirilen sigortalıyı fiilen çalıştırmadığ tespit edilen işyerleri ilk tespitte bir ay süreyle, ilk tespit tarihinden itibaren $\ddot{u} c ̧$ yıl içinde tekrar eden her bir tespit için ise bir yıl süreyle 5510 sayılı Kanun, 3294 sayılı Sosyal Yardımlaşma ve Dayanışmayı Teşvik Kanunu ve 4447 sayılı İşsizlik Sigortası Kanununda yer alan sigorta primi teşvik, destek ve indirimlerden yararlanamamaktadırlar (Başbuğ, 2013, s.108). Bu uygulama doktrinde tartışmalıdır. Bazı görüş sahipleri alt işverenin borcundan dolayı asıl işverene müeyyide uygulanmaması gerektiğini belirtirken bir kısım görüş sahipleri ise alt işverenin işçilerinin asıl işverenin işyerinde çalışmaları nedeniyle asıl işvereni de sorumlu tutmanın doğru olduğunu belirtmektedirler (Yetik, 2018, s.193). Bununla birlikte anılan maddenin 3. fikrasına göre, beş kişiden fazla olmamak koşuluyla çalıştırılan toplam sigortalı sayısının \%1'ini aşmayan 
sayıda, çalıştırılanların sigortalı olarak bildirilmediğinin veya bildirilen kişilerin fiilen çalışmadığının tespit edilmesi hâlinde ise yukarıda belirttiğimiz ek 14. maddenin 1. fikrasındaki hüküm uygulanmayacak olup işveren teşvikten yararlanmaya devam edecektir. Kanaatimizce bu durum işverenlerin lehine olmakla birlikte kayıt dışılığı özendirmesi sebebiyle doğru değildir (Güzel vd. 2018, s.305).

Ayrıca, 5335 sayılı Kanunun 30. maddesinin 2. fikrası kapsamına giren ve kamu kurum ve kuruluşları olarak ifade edilen "genel bütçeye dahil daireler, katma bütçeli idareler, döner sermayeler, fonlar, belediyeler, il özel idareleri, tarafından kurulan birlik ve işletmeler, sosyal güvenlik kurumları, bütçeden yardım alan kuruluşlar ile özel kanunla kurulmuş diğer kamu kurum, kurul, üst kurul ve kuruluşları, kamu iktisadi teşebbüsleri ve bunların bağlı ortaklıkları ile müessese ve işletmelerinde ve sermayesinin \%50'sinden fazlası kamuya ait olan diğer ortaklıklar” ile 2886 sayılı Devlet İhale Kanunu, 4734 sayılı Kamu İhale Kanunu ile 4734 sayılı Kanunun 3. maddesi kapsamındaki istisnalar dahil devletten alım ve yapım işi üstlenen işverenler ile uluslararası anlaşmalara istinaden alım ve yapım işi üstlenen işverenler, ihale konusu iş döneminde bu teşvikten yararlanamazlar (Caniklioğlu, 2011, s.22; Başbuğ, 2013,103). Bu teşvik, 4447 sayılı İşsizlik Sigortası Kanununun 50. maddesinde belirtilen teşvikle birlikte uygulanamaz.

Bu teşvikin bütününe baktığımızda, her ne kadar primlerde indirim sağlıyor olsa da asıl amacının prim tahsilatını artırmak olduğu görülecektir.

\section{Yurtdışına Gönderilen Sigortalılara Uygulanan 5 Puanlık Prim İndirimi (5510/81/1/(i))}

Özel sektör işverenlerinin yararlanabileceği sürekli bir teşvik olan bu teşvikin başlama tarihi 01.06.2013'dür. 5510 sayılı Kanunun 81. maddesinin 1. fikrasina 6486 sayılı Kanunla eklenen (i) bendine göre, özel sektör işverenlerinin yurt dışındaki işyerlerinde çalıştırılmak üzere yurt içinden gönderilen sigortalıları için uygulanan bu indirim kapsamında, sigortalıların prime esas kazançları üzerinden hesaplanan genel sağlık sigortası (GSS) primlerinin işveren hissesinin (\%7,5) 5 puanlık kısmı Hazine tarafından karşılanmaktadır (Tuncay ve Ekmekçi, s.209).

5510 sayılı Kanunun 81. maddesinin 1. fikrasının (1) bendi uyarınca, malullük, yaşlılık ve ölüm sigortası primlerinin işveren hissesinden uygulanacak 5 puanlık indirim için aranan "genel şartlar" bu indirim için de geçerlidir. Bununla beraber Libya'da çalışanlardan, zorunlu staja tabi tutulan öğrenciler, aday çırak, çırak ve işletmelerde mesleki eğitim gören öğrencilerden, iş kaybı tazminatı alanlardan ve harp malulleri ile vazife malullüğü aylığı alanlardan dolayı işverenler bu indirimden yararlanamaz. Bu indirim, 5510 sayılı Kanunun 81. maddesinin 1. fikrasının (1) bendi uyarınca yapılan 5 puanlık indirim ile birlikte uygulanamaz (Tuncay ve Ekmekçi, s.209). Ayrıca, 5335 sayılı Kanunun 30. maddesinin 2. fikrası kapsamına giren ve kamu kurum ve kuruluşlar ile 2886 sayılı Devlet İhale Kanunu, 4734 sayılı Kamu İhale Kanunu ile 4734 sayılı Kanunun 3. maddesi kapsamındaki istisnalar dahil devletten alım ve yapım işi üstlenen işverenler ile uluslararası anlaşmalara istinaden alım ve yapım işi üstlenen işverenler, ihale konusu iş döneminde bu teşvikten yararlanamazlar. 


\section{4/1/(b)'li Sigortalıların Malullük, Yaşııık ve Ölüm Sigortası Primlerinden 5 Puanlık İndirim $(5510 / 81 / 1 /(j))$}

Özel sektör işverenlerinin yararlanabileceği bu teşvikin başlama tarihi 01.06.2016'dır. 5510 sayılı Kanunun 81. maddesinin 1. fikrasının (j) bendine göre, isteğe bağlı sigortalılar ve muhtarlar hariç bu Kanunun 4. maddesinin 1. fikrasının (b) bendi kapsamındaki sigortalıların, malullük, yaşlılık ve ölüm sigortaları (MYÖ) primi olan \%20’lik kısımdan 5 puanlık kısmına isabet eden tutar Hazinece karşılanmaktadır (Sözer, 2017, s.217). Ancak, sigortalıların bu prim indiriminden yararlanabilmeleri için primlerin Hazinece karşllanmayan kısmının yasal süresi içinde Kuruma ödenmesi, kendi sigortalılıklarından kaynaklanan prim, idari para cezası ve bunlara ilişkin gecikme cezası ve gecikme zammı borcunun bulunmaması şarttır. Bununla birlikte Kuruma olan prim, idari para cezası ve bunlara ilişkin gecikme cezası ve gecikme zammı borçlarını taksitlendiren veya yapılandıran sigortalılar bu taksitlendirme veya yapılandırma işlemleri devam ettiği sürece bu hükmünden yararlandırılırlar. Borçlanma ve ihya kapsamındaki primlerden dolayı bu indirimden yararlanılmaz. Hazinece karşılanan prim tutarları gelir ve kurumlar vergisi uygulamalarında gider veya maliyet unsuru olarak dikkate alınmaz. Bu indirim herhangi bir süre sınırına bağlı olmaksızın sürekli olarak uygulanmaktadır. (Yetik, 2018, s.204).

\section{Illave 6 Puanlık Prim İndirimi (5510/81/2)}

30.05.2013 tarihli ve 2013/4966 sayılı Bakanlar Kurulu Kararı eki (I), (II) ve (III) sayılı listelerde yer alan 51 il ile Bozcaada ve Gökçeada ilçelerinde faaliyet gösteren ve 5510 sayılı Kanunun 81 . maddesinin 1. fikrasının (1) bendinde öngörülen beş puanlık indirimden yararlanan özel sektör işverenlerini kapsama alan bu indirimin başlama tarihi 01.01.2013, sona erme tarihi ise 31.12.2018'dir. Bu indirim prime esas kazanç üst sınırına kadar olan kazançlar üzerinden işverenin malullük, yaşlılık ve ölüm sigorta primlerinden (\%11) 5 puanlık indirimin ardından prime esas kazanç alt sınırına kadar olan kazançlar üzerinden hesaplanan malullük, yaşlılık ve ölüm sigorta primlerinden de 6 puanlık indirim sağlanmaktadır. $\mathrm{Bu}$ indirimden yararlanma süreleri illerin gelişmişlik seviyelerine göre 4 yıl, 5 yıl ya da 6 yıl olmak üzere üç ayrı liste halinde belirlenmiştir ${ }^{2}$. Buna göre, I. listede bulunan iller için 4 yll, II. listede bulunan iller için 5 yıl ve III. listede bulunan iller için 6 yıl süreyle bu indirim sağlanacaktır. Ayrıca teşvik süresi 2016 yılında dolan iller için 2016/9728 sayılı Bakanlar Kurulu ile 2017 yılının sonuna kadar uzatılmıştır. 2016/Mart ayından önce prim indiriminden yararlanabilmek için ilgili ayda on ve üzerinde sigortalı çalıştırma şartı bulunmaktaydı. 2016/Mart ayından itibaren bu koşul kaldırılması daha fazla işyerinin yararlanabilmesi açısından isabetli olmuştur (Güzel vd. 2018, s.308; Doğan, N. http://www.hurriyet.com.tr/ik-yeni-ekonomi/2019un-istihdam-tesvikleri410734336).

5510 sayılı Kanunun 81. maddesinin 1. fikrasının (1) bendi uyarınca, malullük, yaşlılık ve ölüm sigortası primlerinin işveren hissesinden uygulanacak 5 puanlık indirim için aranan "genel şartlar” bu indirim için de geçerlidir. Ayrıca, 5335 sayılı Kanunun 30. maddesinin 2. fikrası

\footnotetext{
${ }^{2}$ (4 Yıl) Afyonkarahisar, Amasya, Artvin, Bartın, Çorum, Düzce, Elazığ, Erzincan, Hatay, Karaman, Kastamonu, Kırıkkale, Kırşehir, Kütahya, Malatya, Nevșehir, Rize, Sivas, Trabzon, Ușak (5 Yıl) Adıyaman, Aksaray, Bayburt, Çankırı, Erzurum, Giresun, Gümüşhane, Kahramanmaraş, Kilis, Niğde, Ordu, Osmaniye, Sinop, Tokat, Tunceli, Yozgat (6 Yıl) Ağrı, Ardahan, Batman, Bingöl, Bitlis, Diyarbakır, Hakkâri, Iğdır, Kars, Mardin, Muş, Siirt, Şanlıurfa, Şırnak, Van, Bozcada-Gökçeada
} 
kapsamına giren ve kamu kurum ve kuruluşlar ile 2886 sayılı Devlet İhale Kanunu, 4734 sayılı Kamu İhale Kanunu ile 4734 sayılı Kanunun 3. maddesi kapsamındaki istisnalar dahil devletten alım ve yapım işi üstlenen işverenler ile uluslararası anlaşmalara istinaden alım ve yapım işi üstlenen işverenler, ihale konusu iş döneminde bu teşvikten yararlanamazlar.

5510 sayılı Kanunun Ek 2. maddesinde öngörülen sigorta primi teşvikinden yararlanmakta olan işverenlerin, bu teşvikten yararlandığ 1 süreler içinde Kanunun 81. maddesinin 2. fikrasında öngörülen ilave 6 puanlık sigorta prim indiriminden yararlanamadığını da belirtmek gerekir (Yetik, 2018, s.221).

\section{Yatırımlarda Devlet Yardımları Hakkında Kararlar Uyarınca Uygulanan Teşvik (5510/Ek2)}

Kalkınma Planları ve Yıllık Programlarda öngörülen hedefler ile uluslararası anlaşmalara uygun olarak, tasarrufları katma değeri yüksek yatırımlara yönlendirmek, üretim ve istihdamı artırmak, yatırım eğiliminin devamlılığını ve sürdürülebilir kalkınmayı sağlamak, uluslararası rekabet gücünü artıracak teknoloji ve araştırma geliştirme içeriği yüksek büyük ölçekli yatırımları özendirmek, doğrudan yabancı yatırımları artırmak, bölgesel gelişmişlik farklılıklarını gidermek, çevre korumaya yönelik yatırımlar ile araştırma ve geliştirme faaliyetlerini desteklemek amacıyla özel sektör işverenlerine yönelik olarak 01.10.2009 tarihinde uygulamaya konulmuş bir teşviktir (Umdu ve Yıldız, 2010, s.193). Bu teşvik, Bakanlar Kurulunun 14.07.2009 tarihli ve 2009/15199 sayılı Kararı ile yürürlüğe konulan Yatırımlarda Devlet Yardımları Kararı uygulanmasına ilişkin usul ve esasları belirlemek üzere Hazine Müsteşarlı̆̆ınca çıkarılan Yatırımlarda Devlet Yardımları Hakkında Kararın uygulanmasına ilişkin 2009/1 no’lu tebliğde düzenlenmiştir. Tebliğde belirtilen yatırımların yer aldığı bölgeye göre 2 yıl ile 7 yıl arasında bir süre için prime esas kazanç alt sınırı üzerinden hesaplanan sigorta primlerinin işveren hissesinin Hazine tarafından karşılanması öngörülmüştür. Bu Tebliğin yerini daha sonra Devlet Yatırımları Hakkında Kararın uygulanmasına ilişkin 2012/1 sayılı Tebliğ almıştır. Tebliğin amacı da 15.06.2012 tarihli 2012/3305 sayılı Bakanlar Kurulu kararı ile yürürlüğe konulan Devlet Yardımları Hakkında Kararın uygulanmasına ilişkin usul ve esasları tespit etmektir. Bu tebliğ kapsamında teşvik tanınan işverenlere ilişkin olarak prim desteği getirilmiştir (Güzel vd. 2018, s.309). Anılan tebliğin 14. maddesine göre sigorta primi işveren hissesi desteği, komple yeni yatırımlarda belge kapsamında gerçekleştirilen yatırımla să̆lanan istihdam için diğer yatırım türlerinde ise mevcuda ilave edilen istihdam için uygulanır. Eğer komple yeni yatırım dışındaki yatırım türlerinde prim ve hizmet belgesinde kayıtlı işçi sayısı mevcut istihdamın altında ise ilgili ay için prim desteği uygulanmaz (Olgaç ve Bulut, 2012, s.397).

5510 sayılı Kanunun Ek 2. maddeye göre, yatırımlarda devlet yardımları hakkında kararlar çerçevesinde düzenlenen teşvik belgeleri kapsamında gerçekleştirilecek yatırımlarla istihdam edilen sigortalılar için, 81. maddede sayılan ve 82. madde uyarınca belirlenen prime esas kazanç alt sınırı üzerinden hesaplanan sigorta primlerinin; işveren hisselerinin tamamına veya Cumhurbaşkanınca istatistiki bölge birimleri sınıflandırması, kişi başına düşen milli gelir veya sosyo-ekonomik gelişmişlik düzeyleri dikkate alınmak suretiyle belirlenen illerde işveren hisseleri ile birlikte sigortalı hisselerinin tamamına kadar olan kısmı Ekonomi Bakanlığı (Sanayi 
ve Teknoloji Bakanlĭğ) bütçesinden karşılanmaktadır. Cumhurbaşkanı ayrıca Ekonomi Bakanlığınca (Sanayi ve Teknoloji Bakanlığı) karşılanacak tutarın uygulama süresini, karşılama oranını ve kapsamını; yatırımın sektörü, büyüklüğü ve bulunduğu illere göre farklılaştırmaya yetkilidir.

Primlerin, Ekonomi Bakanlığınca (Sanayi ve Teknoloji Bakanlı̆̆ı) karşılanabilmesi için işverenlerin, Bakanlıkça düzenlenen Teşvik Belgesi'ni almış olması (Umdu ve Yıldız, 2010, s.199) çalıştırdıkları sigortalılarla ilgili olarak bu Kanun uyarınca aylık prim ve hizmet belgelerinin Kuruma, muhtasar ve prim hizmet beyannamelerinin Hazine ve Maliye Bakanlığına yasal süresi içerisinde vermesi ve Ekonomi Bakanlığınca (Sanayi ve Teknoloji Bakanlığı) karşılanmayan tutarın yasal süresi içinde ödenmiş olması şarttır. İşyerinin 6. Bölgede kurulu olması halinde sigortalı ve işveren hissesi prim tutarının tamamı karşılanır (Yetik, 2018, s.223). Bununla birlikte bu destekten yararlananlar ilave 6 puanlık indirimle aynı dönem için teşvikten yararlanamaz. Teşvikten yararlanacak işverenin başvuru tarihinden önceki 15 gün içinde vadesi geçmiş prim borcunun bulunmaması gerekmektedir.

5510 sayılı Kanunun 81. maddesinin 1. fikrasının (1) bendi uyarınca, malullük, yaşlılık ve ölüm sigortası primlerinin işveren hissesinden uygulanacak 5 puanlık indirim için aranan "genel şartlar” bu indirim için de geçerlidir. Ayrıca, Ayrıca, 5335 sayılı Kanunun 30. maddesinin 2. fikrası kapsamına giren ve kamu kurum ve kuruluşlar ile adına sosyal güvenlik destek primi ödenen sigortalılar teşvikten yararlanamazlar (Olgaç ve Bulut, 2012, s.394, 402 vd.).

Tablo 1'de yukarıda ifade edilen 5510 sayılı Sosyal Sigortalar ve Genel Sağlık Sigortası Kanununda düzenlenen teşvik ve indirimlerin tablo haline getirilmiş özet bilgisi bulunmaktadır.

Tablo 1. 5510 sayılı Kanun kapsamındaki teşvikler ve indirimler

\begin{tabular}{|c|c|c|c|c|c|c|}
\hline Teşvik Türü & $\begin{array}{l}\text { Sektör / } \\
\text { Kapsam }\end{array}$ & $\begin{array}{l}\text { Teşvikin } \\
\text { süresi ve } \\
\text { Bitiş } \\
\text { Tarihi } \\
\end{array}$ & $\begin{array}{l}\text { Prim } \\
\text { Matrahı }\end{array}$ & $\begin{array}{l}\text { Sigorta } \\
\text { Kolu }\end{array}$ & $\begin{array}{l}\text { Teşvik Oranı } \\
\text { / Miktar }\end{array}$ & $\begin{array}{l}\text { Finansman } \\
\text { Kay. }\end{array}$ \\
\hline $\begin{array}{l}\text { 4/1/(a)MYÖ } 5 \\
\text { Puan } \\
(5510 / 81 / 1 /(1))\end{array}$ & Özel Sektör & Sürekli / - & PEK & YMÖ & $\begin{array}{l}\text { İşv. His. \%5 } \\
\text { indirim }\end{array}$ & Hazine \\
\hline $\begin{array}{l}\text { Yurt D1ş1 } 5 \\
\text { Puan } \\
(5510 / 81 / 1 /(i))\end{array}$ & $\begin{array}{l}\text { Özel Sektör / } \\
\text { Yurt D1ş1 }\end{array}$ & Sürekli / - & PEK & GSS & $\begin{array}{l}\text { İşv. His. \%5 } \\
\text { indirim }\end{array}$ & Hazine \\
\hline $\begin{array}{l}\text { 4/1/(b)MYÖ } 5 \\
\text { Puan } \\
(5510 / 81 / 1 /(\mathrm{j}))\end{array}$ & Özel Sektör & Sürekli / - & PEK & YMÖ & $\begin{array}{l}\text { Primlerden } \\
\% 5 \text { indirim }\end{array}$ & Hazine \\
\hline $\begin{array}{l}\text { İlave } 6 \text { Puan } \\
(5510 / 81 / 2)\end{array}$ & $\begin{array}{l}\text { Özel Sektör / } \\
\text { \%51 İl + } \\
\text { Bozcaada ve } \\
\text { Gökçeada } \\
\end{array}$ & $\begin{array}{l}\text { Sürekli / } \\
31.12 .2019\end{array}$ & $\begin{array}{l}\text { PEK Alt } \\
\text { Sinır1 }\end{array}$ & YMÖ & $\begin{array}{l}\text { İşv. His. \%5 } \\
\text { indirim }\end{array}$ & Hazine \\
\hline \multirow{2}{*}{$\begin{array}{l}\text { Yat Dev. Yard. } \\
\text { (5510/Ek2) }\end{array}$} & $\begin{array}{l}\text { Özel Sektör / } \\
\text { Genel }\end{array}$ & Sürekli / - & $\begin{array}{l}\text { PEK Alt } \\
\text { Sinırı }\end{array}$ & $\begin{array}{l}\text { MYÖ } \\
\text { İKMH;H;A } \\
\text { GSS }\end{array}$ & $\begin{array}{l}\text { İşv. His. } \\
\text { Tamamı }\end{array}$ & \multirow{2}{*}{$\begin{array}{l}\text { Ekonomi } \\
\text { Bakanlığ } \\
\text { (Sanayi ve } \\
\text { Teknoloji } \\
\text { Bakanlığı) }\end{array}$} \\
\hline & $\begin{array}{l}\text { Özel Sektör / } \\
\text { Belirli İllerde }\end{array}$ & Sürekli / - & $\begin{array}{l}\text { PEK Alt } \\
\text { Sinırı }\end{array}$ & $\begin{array}{l}\text { MYÖ } \\
\text { İKMH;H;A } \\
\text { GSS }\end{array}$ & $\begin{array}{l}\text { İşv. } \\
\text { Tamamı }+ \\
\begin{array}{l}\text { Sig. } \\
\text { Tamamı }\end{array} \\
\text { His. }\end{array}$ & \\
\hline
\end{tabular}




\section{İşsizlik Ödeneği Alanların İstihdamı Halinde Uygulanan Prim Teşviki (4447/50/5)}

Özel sektör işverenlerinin yararlanabileceği bu teşvikin başlama tarihi 01.10.2009'dur. 4447 sayılı Kanunun 50. maddesinin mülga 5. fikrasının 5921 sayılı Kanunun 1. maddesiyle yeniden düzenlenmiş şekline göre, işsizlik ödeneği alanların; işe alındığı tarihten önceki aydan başlayarak işe alan işyerine ait son altı aylık dönemde, prim ve hizmet belgelerinde bildirilen ortalama sigortalı sayısına ilave olarak işe alınması kaydıyla, 5510 sayılı Kanunun 81. maddesinde sayılan ve 82. maddesi uyarınca belirlenen prime esas kazanç alt sinırı üzerinden hesaplanan kısa vadeli sigorta primi tutarının \%1’i olmak üzere işçi ve işveren payı sigorta primleri ile genel sağlık sigortası primi, kalan işsizlik ödeneği süresince İssizlik Sigortası Fonundan karşılanır. Bu teşviki diğer uygulamalardan ayıran en belirgin özellik bunun sadece işveren hissesine yönelik değil, işçi hissesini de kapsayacak şekilde düzenlenmiş olmasıdır (Tuncay ve Ekmekçi, s.199).

Söz konusu primlerin İşsizlik Sigortası Fonundan karşılanabilmesi için işverenlerin çalıştırdıkları sigortalılarla ilgili olarak 5510 sayılı Kanun uyarınca aylık prim ve hizmet belgelerini yasal süresi içerisinde Sosyal Güvenlik Kurumuna vermesi, varsa prime esas alt kazanç sınırı ile prime esas kazanç arasındaki fark ve kısa vadeli sigorta kollarına ilişkin prim tutarı farkı ile işsizlik sigortası primlerini Sosyal Güvenlik Kurumuna ödemiş olması şarttır (Caniklioğlu, 2011, s.22).

Bu teşvik, 5510 sayılı Kanun kapsamında bulunanlarla aynı şartlarda olmak üzere 506 sayılı Kanunun geçici 20. maddesi kapsamındaki sandıkların statülerine tabi personeli için de uygulanır. Bu destek unsurundan diğer ilgili mevzuat uyarınca ayrıca yararlanmakta olan işverenler; aynı dönem için ve mükerrer olarak bu destek unsurundan yararlanamaz. $\mathrm{Bu}$ durumda, işverenlerin tercihleri dikkate alınmak suretiyle uygulama, destek unsurlarından sadece biriyle sınırlı olarak yapılır. Ayrıca, işçinin, işten ayrıldığı işyerinde tekrar işe başlaması halinde bu teşvik hükümlerinden yararlanılamaz. Bu teşvik, 21.04.2005 tarihli ve 5335 sayılı Bazı Kanun ve Kanun Hükmünde Kararnamelerde Değişiklik Yapılmasına Dair Kanunun 30. maddesinin 2. fikrası kapsamına giren kurum ve kuruluşlara ait işyerlerinde çalışmaya başlayanlar ve 4734 sayılı Kanun kapsamındaki işyerleri hakkında uygulanmaz.

$\mathrm{Bu}$ teşvikte yukarıda da belirttiğimiz gibi işveren prim payının yanında sigortalı prim payı da karşılanmaktadır. Kapsama giren sigortalı için, işsizlik ödeneğine hak kazandığı süre boyunca prime esas kazanç alt sınırı üzerinden hesaplanan kısa vadeli sigorta primlerinin \% 1’i, uzun vadeli sigorta primi olan toplam \%20 ve genel sağlık sigortası primi olan $\% 12,5$ priminin tamamı kalan işsizlik ödeneği süresince İşsizlik Sigortası Fonundan karşılanmaktadır (Caniklioğlu, 2011, s.166). Bu teşvik 5 puan indirim ile birlikte uygulanmaz.

Yukarıda belirttiğimiz koşullara ek olarak; işyeri yönünden; belirtmeliyiz ki, sigortalının, işe alındığı tarihten önceki son altı aylık dönemde Kuruma bildirilen sigortalı sayısının ortalamasına ilave olarak çalıştırılması; sigortalı yönünden ise 01.10.2009 veya sonraki bir tarihte işe alınmış olması, işe giriş tarihi itibariyle işsizlik ödeneği almaya hak kazanmış olması, sigortalı, işsizlik ödeneği almaya hak kazanmadan önce son çalıştığı işyeri haricindeki bir 
işyerinde işe başlamış olması ve fiilen çalışması gerekmektedir. Bu teşvikin süresinin de en az 6 ay en çok da 10 ay olan işsizlik ödeneğinin ödenme süresi kadar olduğunu belirtmek gerekir (Yetik,2018, s.275).

5510 sayılı Kanunun 81. maddesinin 1. fikrasının (1) bendi uyarınca, malullük, yaşlılık ve ölüm sigortası primlerinin işveren hissesinden uygulanacak 5 puanlık indirim için aranan "genel şartlar” bu indirim için de geçerlidir. Ancak, 5510 sayılı Kanunun ek 14. maddesi hükümleri bu teşvikte uygulanmaz.

\section{Genç, Kadın ve Mesleki Belge Sahibi Olanların İstihdamına Yönelik Teşvik (4447/Geçici 10)}

Genç ve kadın işçilerin istihdam oranlarının düştüğü son ylllarda özellikle genç işçilerle kadın işçilerin istihdamını artıııı nitelikte prim teşvikleri uygulanmaktadır. 01.03.2011-31.12.2020 tarihi arasında işe alınmış olması şartıyla özel sektör işverenlerine, bu tarihler arasında işe aldıkları sigortalılar için, primine esas kazançları üzerinden hesaplanan sigorta primi işveren payı olan \%20,5 tamamının İşsizlik Sigortası Fonundan karşılanmasına imkân sağlanmıştır. Teşvikten yararlanabilmek için, sigortalının 18 yaşından büyük olması, işe alındığı tarihten önceki altı aylık dönemde işsiz olması, ortalama sigortalı sayısına ilave olarak çalıştırılması ve fiilen çalışması gerekmektedir. Ortalama sigortalı sayısının tespitinde hem asıl işveren hem de alt işverenler tarafından çalıştırılan sigortalılar dikkate alınmaktadır (Alper, 2017, s. 241).

18-29 yaş arası erkekler ile 18 yaşından büyük kadınlardan mesleki yeterlik belgesine sahip olanlar için 48 ay, mesleki ve teknik eğitim veren orta veya yükseköğretim kurumlarından mezun olanlar veya Türkiye İş Kurumunca düzenlenen işgücü yetiştirme kurslarını bitirenler için 36 ay, burada belirtilen niteliklere sahip olmayanlar için ise 24 ay süreyle teşvikten yararlanmak mümkündür. Görüleceği üzere, bu teşvikten yararlanma süresi, kapsama giren sigortalının yaşına, mesleki yeterlik belgesine sahip olup olmamasına, mesleki ve teknik eğitim veren orta öğretim veya yükseköğretim kurumlarını tamamlayıp tamamlamamış olmasına, Türkiye İş Kurumu tarafından düzenlenen iş gücü yetiştirme kurslarını bitirip bitirmemesine veya Türkiye İş Kurumuna kayıtlı bir işsiz olup olmamasına göre farkllılklar göstermektedir. Mesleki yeterlilik belgesine sahiplik nedeniyle teşvikten yararlanma durumunda bu belgenin TC Mesleki Yeterlilik Kurumundan alınmış olması gerekmektedir (Tuncay ve Ekmekçi, 2017, s.204; Yetik, 2018, s.240).

29 yaşından büyük erkeklerden; mesleki yeterlik belgesi alanlar veya mesleki ve teknik eğitim veren orta veya yükseköğretim kurumlarını ya da Türkiye İş Kurumunca düzenlenen işgücü yetiştirme kursunu bitiren ve belgede belirtilen meslek ya da alanlarda işe alınan ve/veya çalıştırılan için 24 ay, Türkiye İş Kurumuna kayıtll, Kanunda sayılan belgelere sahip olmayanlar için 6 ay, 5510 sayılı Kanunun 4/1/(a) bendi kapsamında çalışmakta iken, 01.03.2011 tarihinden sonra mesleki yeterlik belgesi alanlar veya mesleki ve teknik eğitim veren orta veya yükseköğretim kurumlarını bitirenler ise 12 ay süreyle teşvikten yararlanırlar (Alper, 2017, s.241; http://www.sgk.gov.tr/ İstihdam Teşvikleri Hakkında Bilinmesi Gerekenler). 
Bu kapsama girenlerin Türkiye İş Kurumuna kayıtlı işsizler arasından işe alınmaları halinde ise teşvik süresine 6 ay daha ilave edilmektedir.

Bu teşvikten aynı sigortalı için bir kez yararlanılabilir. 5510 sayılı Kanunun 81. maddesinin 1. fikrasının (1) bendi uyarınca, malullük, yaşlılık ve ölüm sigortası primlerinin işveren hissesinden uygulanacak 5 puanlık indirim için aranan "genel şartlar" bu indirim için de geçerlidir. Ayrıca, 5335 sayılı Kanunun 30. maddesinin 2. fikrası kapsamına giren ve kamu kurum ve kuruluşlar ile 2886 sayılı Devlet İhale Kanunu, 4734 sayılı Kamu İhale Kanunu ile 4734 sayılı Kanunun 3. maddesi kapsamındaki istisnalar dahil devletten alım ve yapım işi üstlenen işverenler ile uluslararası anlaşmalara istinaden alım ve yapım işi üstlenen işverenler, ihale konusu iş döneminde bu teşvikten yararlanamazlar.

5510 sayılı Kanun gereğince yapılan kontrol ve denetimlerde, çalıştırdığı kişileri sigortalı olarak bildirmediği tespit edilen işverenler bir yıl süreyle bu teşvikten yararlanamaz. Bu teşvik, 5510 sayılı Kanunun 81. maddesinin 1. fikrasının (1) bendinde belirtilen malullük, yaşlılık ve ölüm (MYÖ) sigortaları primlerinin işveren hissesinden yapılan 5 puanlık indirim uygulandıktan sonra kalan sigorta primlerinin işveren hisselerine ait oranın uygulanması bakımından önemlidir (SGK Başkanlığı, 2013, 276; http://istihdamatesvik.com/teşvikler).

\section{İşbaşı Eğitim Programını Tamamlayanların İstihdamına Yönelik Teşvik (4447/Geçici15)}

Prim teşviki kapsamında en son olarak 04.04.2015 tarih ve 6645 sayll Torba Kanunun 28. maddesi ile 4447 sayılı Kanuna eklenen geçici 15. madde ile işbaşı eğitim programını (İEP) tamamlayanların istihdamına ilişkin yeni bir teşvik getirilmiştir. 23.04.2015 tarihinde başlayan bu teşvike göre, Türkiye İş Kurumu tarafından 31.12.2017 tarihine kadar başlatılan işbaşı eğitim programlarını tamamlayan 18 yaşından büyük, 29 yaşından küçükleri üç ay içinde işe alan özel sektör işverenlerine, bu sigortalılar için, primine esas kazanç alt sınırı üzerinden hesaplanacak sigorta primi işveren payının $(\% 20,5)$ tamamının işe alındıkları işyerinin imalat sanayinde faaliyet göstermesi hâlinde 42 ay, diğer sektörlerde ise 30 ay süre İssizlik Sigortası Fonundan karşılanmaktadır (http://www.sgk.gov.tr/wps/portal/sgk/tr/calisan/isveren/ist-tesvikleri; Alper, 2017, s.243).

Sigortalının, ortalama sigortalı sayısına ilave olarak çalıştırılması ve sigortalı tamamladığı işbaşı eğitim programına ilişkin meslek alanında işe alınması koşuluyla 5510 sayılı Kanunun 81. maddesinin 1. fikrasinin (i) bendindeki belirtilen 5 puan indirim uygulandiktan sonra kalan sigorta primlerinin işveren hisselerine prime esas kazanç alt sınırı üzerinden hesaplanan tutar İssizlik Sigortası Fonundan karşılanır (Güzel vd. 2018, s.314).

5510 sayılı Kanunun 81. maddesinin 1. fikrasının (1) bendi uyarınca, malullük, yaşlılık ve ölüm sigortası primlerinin işveren hissesinden uygulanacak 5 puanlık indirim için aranan "genel şartlar” bu indirim için de geçerlidir. Ancak, 5510 sayılı Kanunun ek 14. maddesi hükümleri bu teşvikte uygulanmaz. 
Bu teşvik, 5335 sayılı Kanunun 30. maddesinin 2. fikrası kapsamına giren kurum ve kuruluşlara ait işyerleri ile 2886 sayılı Devlet İhale Kanununa, 4734 sayılı Kamu İhale Kanununa ve uluslararası anlaşma hükümlerine istinaden yapılan alım ve yapım işleri ile 4734 sayılı Kanundan istisna olan alım ve yapım işlerine ilişkin işyerleri, sosyal güvenlik destek primine tabi çalışanlar ve yurt dışında çalışan sigortalılar hakkında uygulanmaz.

Fondan karşılanan prim tutarları, gelir ve kurumlar vergisi uygulamalarında gider veya maliyet unsuru olarak dikkate alınmaz.

\section{İsveren Desteği (4447/Geçici 19)}

Kuruma kayıtlı işsizler arasından, 01.01.2018 ila 31.12.2020 tarihleri arasında özel sektör işverenlerince 5510 sayılı Kanunun 4/1/(a) bendi kapsamında işe alınanların; işe girdikleri aydan önceki üç aylık sürede toplam on günden fazla 5510 sayılı Kanunun 4/1/(a) ve (c) bentleri kapsamında Sosyal Güvenlik Kurumuna bildirilmemiş olmaları ve isteğe bağlı sigortalılık hariç 5510 sayılı Kanun'un 4/1/(b) bendi kapsamında sigortalı olmaması ve işe alındıkları yıldan bir önceki takvim yılında işe alındıkları işyerinden bildirilen aylık prim ve hizmet belgelerindeki veya muhtasar ve prim hizmet beyannamelerindeki sigortalı sayısının ortalamasına ilave olmaları kaydıyla, işyerinin imalat veya bilişim sektöründe_faaliyet göstermesi halinde ilgili döneme ait günlük brüt asgarî ücretin sigortalının prim ödeme gün sayısıyla çarpımı sonucu bulunacak tutarı geçmemek üzere, sigortalının prime esas kazançları üzerinden hesaplanan sigortalı ve işveren hissesi primlerinin $(\% 34,5)$ tamamı tutarında; işyerinin diğer sektörlerde faaliyet göstermesi halinde sigortalının 5510 sayılı Kanunun 82. maddesi uyarınca belirlenen prime esas kazanç alt sınırı üzerinden hesaplanan sigortalı ve işveren hissesi primlerinin $(\% 34,5)$ tamamı tutarında, her ay bu işverenlerin SGK'ya ödeyecekleri tüm primlerden mahsup edilmek suretiyle işverene prim desteği sağlanır ve destek tutarı İşsizlik Sigortası Fonundan karşlanır (Yetik, 2018, s.302; Ünlü, http://www.muhasebetr.com/yazarlarimiz/kenanozdemir/001/).

Destek kapsamına giren sigortalılar için 12 ay süreyle uygulanır. Ancak, bu süre işe giriş tarihi itibarıyla 18 yaşından büyük kadın, 18 yaşından büyük 25 yaşından küçük erkek sigortalılar ile Kuruma engelli olarak kayıtlı sigortalılar için 18 ay olarak uygulanır (http://iskanunu.com/kanun-ve-yonetmelikler/son-degisiklikler/2018-torba-yasa-tesvikleri/; Alper, 2017, s.243; Ünlü, 2018, s.239).

5510 sayılı Kanunun 81. maddesinin 1. fikrasının (1) bendi uyarınca, malullük, yaşlllık ve ölüm sigortası primlerinin işveren hissesinden uygulanacak 5 puanlık indirim için aranan "genel şartlar” bu teşvik için de geçerlidir.

Mahkeme kararıyla veya yapılan kontrol ve denetimlerde çalıştırdığı kişileri sigortalı olarak bildirmediği veya bildirilen sigortalıyı fiilen çalıştırmadığı tespit edilen işyerleri hakkında, 5510 sayılı Kanunun ek 14 üncü maddesi uyarınca işlem yapılır. Ancak ek 14. maddenin 3. fikrasına göre, beş kişiden fazla olmamak koşuluyla çalıştırılan toplam sigortalı sayısının \%1'ini aşmayan sayıda, çalıştırılanların sigortalı olarak bildirilmediğinin veya bildirilen kişilerin fiilen 
çalışmadığının tespit edilmesi hâlinde ek 14. maddenin 1. fikrasındaki hüküm uygulanmayacaktır³. Belirtelim ki, bu durum işverenlerin lehine olmakla birlikte kayıt dışılığ özendirmesi sebebiyle doğru değildir. Bu teşvik; 5335 sayılı Kanunun 30. maddesinin 2. fikrası kapsamına giren kurum ve kuruluşlara ait işyerleri ile 2886 sayılı Devlet İhale Kanununa, 4734 sayılı Kamu İhale Kanununa ve uluslararası anlaşma hükümlerine istinaden yapılan alım ve yapım işleri ile 4734 sayılı Kanundan istisna olan alım ve yapım işlerine ilişkin işyerleri ile sosyal güvenlik destek primine tabi çalışanlar ve yurtdışında çalışan sigortalılar hakkında uygulanmaz. Sağlanan teşvikten yararlanmakta olan işverenler, bu teşvikten yararlanılan ayda aynı sigortalı için diğer sigorta primi teşvik, destek ve indirimlerinden yararlanamaz (Özcan, C. https://www.dunya.com/kose-yazisi/yeni-istihdama-2020-yilina-kadar-prim-gelir-vergisi-vedamga-vergisi-tesviki/40193; Gündüz, 2018, s.230).

Bu teşvikten yararlanmakta olan işverenler, teşvikten yararlanılan ayda aynı sigortalı için diğer sigorta prim teşvik, destek ve indirimlerinden yararlanamaz. Ancak, işverenlerin aynı anda aynı sigortalı için birden fazla teşvikten yararlanması mümkündür. Böyle durumlarda öncelikle, 5510 sayılı Kanunun 81. maddesinin 1. fikrasının (1) bendi uyarınca, malullük, yaşlılık ve ölüm sigortası primlerinin işveren hissesinden 5 puanlık indirim uygulanacak, ardından prime esas kazanç alt sınırına kadar olan kazançlar üzerinden kalan işveren hissesine karşılık gelen tutarın toplamı kadar yararlanılacaktır.

\section{İşveren Desteği-Bir Senden Bir Benden (4447/Geçici 20)}

2017 yılında Sosyal Güvenlik Kurumuna verilen aylık prim ve hizmet belgelerinde kayıtlı sigortalı sayısı ortalaması 1 ila 3 olan, imalat sektöründe_faaliyet gösteren ve bu sektörde ustalık belgesi sahibi olunan özel sektöre ait işyerlerince, işe giriş tarihi itibarıyla 18 yaşından büyük ve 25 yaşından küçük sigortalılardan ve Kuruma kayıtlı işsizler arasından olmak kaydıyla 01.01.2018 tarihinden itibaren 5510 sayılı Kanunun 4/1/(a) bendi kapsamında işe alınanların; işe girdikleri aydan önceki üç aylık sürede toplam on günden fazla 5510 sayılı Kanunun 4/1/(a) ve (c) bentleri kapsamında SGK'ya bildirilmemiş olmaları ve isteğe bağlı sigortalılık hariç 5510 sayılı Kanunun 4/1/(b) bendi kapsamında sigortalı olmamaları, 2017 yılında SGK'ya bildirilen aylık prim ve hizmet belgelerinde veya muhtasar ve prim hizmet beyannamelerinde kayıtlı sigortalı sayısının ortalamasına ilave olmaları kaydıyla, işe alındıkları tarihten 2018 yılı Aralık ayına kadar geçerli olmak üzere, destek kapsamına giren sigortalılar için 5510 sayılı Kanunun 82. maddesi uyarınca belirlenen prime esas kazanç alt sınırı üzerinden hesaplanan sigortalı ve işveren hissesi primlerinin (\%34,5) tamamı tutarında bu işverenlerin SGK'ya ödeyecekleri tüm primlerden mahsup edilmek suretiyle işverene prim desteği sağlanır ve destek tutarı İssizlik $\begin{array}{lllll}\text { Sigortası Fonundan } & \text { karşılanır } & \text { (Gündüz, } & \text { 2018, } & \text { s.233 }\end{array}$ http://www.muhasebetr.com/yazarlarimiz/kenanozdemir/001/).

\footnotetext{
${ }^{3} 5510$ s. Kanun Ek Madde14/1: Mahkeme kararıyla veya yapılan kontrol ve denetimlerde çalıştırdığı kişileri sigortalı olarak bildirmediği veya bildirilen sigortalıyı fiilen çalıştırmadığı tespit edilen işyerleri ilk tespitte bir ay süreyle, ilk tespit tarihinden itibaren üç yıl içinde tekrar eden her bir tespit için ise bir yıl süreyle bu Kanun, 3294 sayılı Sosyal Yardımlaşma ve Dayanışmayı Teşvik Kanunu ve 4447 sayılı İssizlik Sigortası Kanununda yer alan sigorta primi teşvik, destek ve indirimlerden yararlanamaz. Bu Kanun ve 3294 sayılı Kanun ile 4447 sayılı Kanunda bu maddeye aykırı olan hükümler uygulanmaz.
} 
Destek kapsamındaki sigortalılar için yukarıda belirtilen prim desteğiyle birlikte ayrıca 2018 yılı Aralık ayına kadar geçerli olmak üzere; sigortalının destek sağlanan aya ilişkin prim ödeme gün sayısının 53,44 TL ile çarpılması sonucu bulunacak tutar, ücret desteği olarak Kurum tarafından işverene ödenir ve destek tutarı Fondan karşılanır (Gündüz, 2018, s.233; http://iskanunu.com/kanun-ve-yonetmelikler/son-degisiklikler/2018-torba-yasa-tesvikleri).

Bu maddeyle sağlanan prim ve ücret desteği 2018 yılı Aralık ayını geçmemek üzere, sigortalının işe alındığı ayı takip eden ilk aydan başlamak üzere her ikinci ay için uygulanır (Gündüz, 2018, s.233; http://iskanunu.com/kanun-ve-yonetmelikler/son-degisiklikler/2018-torba-yasatesvikleri).

İșe giriş tarihi itibarıla sigortalının, işverenin birinci derece kan veya kayın hısmı ya da eşi olması durumunda söz konusu sigortalıdan dolayı bu maddede yer alan destekten yararlanılamaz. Sigortalının işe giriş tarihinden sonra işverenle arasında oluşan hısımlık veya evlilik durumları destekten yararlanmayı etkilemez.

Bu kapsamdaki destekten yararlanılan ayda aynı sigortalı için diğer sigorta primi teşvik, destek ve indirimlerden yararlanılamaz. Bu destekten yararlanılmayan ayda destek kapsamına giren sigortalıdan dolayı, 5510 sayılı Kanunun 81. maddenin 1. fikrasının (1) bendi ile aynı maddenin 2. fikrasında yer alan prim indirimi dışındaki diğer sigorta primi teşvik, destek ve indirimlerden yararlanilamaz.

Fondan bu teşvik kapsamında karşılanan tutarlar, gelir ve kurumlar vergisi uygulamalarında gelir, gider veya maliyet unsuru olarak dikkate alınmaz.

5335 sayılı Kanunun 30. maddesinin 2. fikrası kapsamına giren kurum ve kuruluşlara ait işyerleri ile 2886 sayılı Devlet İhale Kanununa, 4734 sayılı Kamu İhale Kanununa ve uluslararası anlaşma hükümlerine istinaden yapılan alım ve yapım işleri ile 4734 sayılı Kanundan istisna olan alım ve yapım işlerine ilişkin işyerleri ve sosyal güvenlik destek primine tabi çalışanlar ve yurtdışında çalışan sigortalılar hakkında uygulanmaz (Yetkin, 2018, s.3 06).

Mahkeme kararıyla veya yapılan kontrol ve denetimlerde çalıştırdığı kişileri sigortalı olarak bildirmediği veya bildirilen sigortalıyı fiilen çalıştırmadığı tespit edilen işyerleri hakkında, 5510 sayılı Kanunun ek 14. maddesi uyarınca işlem yapılır. Ancak, 14. madde ile ilgi yukarıda yaptığımız eleştiri bu teşvik için de geçerlidir.

4447 Sayılı Kanunun Geçici 19. ve Geçici 20. Maddeleri Kapsamında İşe Alınanların
Ücretlerine Yönelik Gelir vergisi Teşviki (4447/Geçici 21) 4447 sayılı Kanunun geçici 19. ve geçici 20. maddeleri kapsamında işe alınanların ücretlerinin, ilgili yılda uygulanan asgarî ücretin aylık brüt tutarının prim ödeme gün sayısına isabet eden tutarı üzerinden hesaplanan gelir vergisinin asgarî geçim indirimi uygulandıktan sonra kalan kısmı, verilecek muhtasar beyanname üzerinden tahakkuk eden vergiden terkin edilir (Gündüz, 2018, s.236). 
Dolayısıyla, ek istihdam sağlayan işverenlere belli bir sınır ve süre çerçevesinde sağlanan avantaj, indirim şeklinde değil, tahakkuk eden verginin terkini suretiyle sağlanmakta olup, getirilen teşvikten, sigortalı değil ek istihdam sağlayan işveren yararlanmaktadır. Bu teşvik kapsamında yapılan ücret ödemelerine ilişkin düzenlenen kâğıtlara ait damga vergisinin aylık brüt asgarî ücretin prim ödeme gün sayısına isabet eden kısmı beyan edilmez ve ödenmez. $\mathrm{Bu}$ teşvikle sağlanan vergi teşvikleri 2020 yılı Aralık ayı aşılmamak üzere, teşvik kapsamına giren çalışanlar için 12 ay süreyle uygulanır. Ancak bu süre; işe giriş tarihi itibarıyla teşvik kapsamına giren; 18 yaşından büyük kadın, 18 yaşından büyük 25 yaşından küçük erkek çalışanlar ile Kuruma engelli olarak kayıtlı sigortalılar için 18 ay olarak uygulanır. Bu kapsamındaki vergi teşvikleri, 4447 sayılı Kanunun geçici 20. maddesi kapsamında sağlanan teşvikten yararlanılan çalışanlar için maddede yazılı süre ve şartlarla sınırlı olarak uygulanır, prim ve ücret desteği sağlanmayan aylar için vergi teşvikleri de uygulanmaz (Özcan, C. https://www.dunya.com/kose-yazisi/yeni-istihdama-2020-yilina-kadar-prim-gelir-vergisi-vedamga-vergisi-tesviki/401933).

Bu teşvik kapsamında gelir vergisi stopajı teşvikinden yararlananlar, diğer kanunlarda yer alan benzer nitelikli gelir vergisi stopajı teşviklerinden yararlanamaz.

Bu teşvik; 5335 sayılı Kanunun 30. maddesinin 2. fikrası kapsamına giren kurum ve kuruluşlara ait işyerleri ile 2886 sayılı Devlet İhale Kanununa, 4734 sayılı Kamu İhale Kanununa ve uluslararası anlaşma hükümlerine istinaden yapılan alım ve yapım işleri ile 4734 sayılı Kanundan istisna olan alım ve yapım işlerine ilişkin işyerleri ile sosyal güvenlik destek primine tabi çalışanlar ve yurtdışında çalışan sigortalılar hakkında uygulanmaz.

\section{İş Sağlığı ve Güvenliği Önlemlerini Teşvik (4447/Ek4)}

4447 sayılı Kanunun ek 4. maddesine göre, 6331 sayılı İş Sağlı̆̆ı ve Güvenliği Kanunu kapsamında çok tehlikeli sınıfta yer alan ondan fazla çalışanı bulunan ve üç yıl içinde ölümlü veya sürekli iş göremezlikle sonuçlanan iş kazası meydana gelmeyen işyerlerinde çalışanların işsizlik sigortası işveren payı (\%2) teşvik olarak bir sonraki takvim yılından geçerli olmak üzere ve üç yıl süreyle \%1 olarak alınır (Tuncay ve Ekmekçi, 2017, s.208).

Ölümlü veya sürekli iş göremezlikle sonuçlanan iş kazası meydana gelmesi hâlinde takip eden aydan itibaren bu teşvik uygulamasına son verilir. Burada belirtilen teşvikten yararlanan işverenlerden iş kazalarını bildirmeyenler, iş kazasının meydana geldiği tarihten itibaren yararlandıkları primleri yasal faizi ile birlikte geri öderler ve bu teşvikten 5 yıl süre ile yasaklanırlar. Niteliği itibariyle sürekli bir teşviktir. Teşvikin amacı çok tehlikeli sınıfta meydana gelebilecek iş kazalarının önlenmesidir. İş kazaları, iş kazası ve meslek hastalıkları sigortası ile ilişkili olmasına rağmen prim teşviki işsizlik sigortası primlerine uygulanmaktadır (Güzel vd, 2018, 313; Yetik, 2018, s.294).

Tablo 2'de yukarıda ifade edilen 4447 sayılı İşsizlik Sigortası Kanununda düzenlenen teşvik ve desteklerin tablo haline getirilmiş özet bilgisi bulunmaktadır. 
Tablo 2. 4447 sayılı Kanun kapsamındaki teşvik ve destekler

\begin{tabular}{|c|c|c|c|c|c|c|}
\hline Teşvik Türü & $\begin{array}{l}\text { Sektör / } \\
\text { Kapsam }\end{array}$ & $\begin{array}{l}\text { Teşvikin } \\
\text { süresi ve } \\
\text { Bitiş } \\
\text { Tarihi }\end{array}$ & $\begin{array}{l}\text { Prim } \\
\text { Matrahı }\end{array}$ & $\begin{array}{l}\text { Sigorta } \\
\text { Kolu }\end{array}$ & $\begin{array}{l}\text { Teşvik Oranı / } \\
\text { Miktar }\end{array}$ & $\begin{array}{l}\text { Finansman } \\
\text { Kay. }\end{array}$ \\
\hline $\begin{array}{l}\text { İşsizlik Öden. } \\
\text { Alan. İstih. } \\
(4447 / 50 / 5)\end{array}$ & Özel Sektör & $\begin{array}{l}\text { İşsizlik } \\
\text { ödeneğine } \\
\text { hak } \\
\text { kazandığı } \\
\text { süre } \\
\text { boyunca / - }\end{array}$ & $\begin{array}{l}\text { PEK Alt } \\
\text { Sinırı }\end{array}$ & $\begin{array}{l}\text { MYÖ } \\
\text { İKMH;H;A } \\
\text { GSS }\end{array}$ & $\begin{array}{l}\text { MYÖ Tamamı } \\
\text { İKMH,H,A \%1 } \\
\text { GSS Tamamı }\end{array}$ & $\begin{array}{l}\text { İşs. Sig. } \\
\text { Fonu }\end{array}$ \\
\hline $\begin{array}{l}\text { Genç, Kadın, } \\
\text { Mes. Belgeli } \\
(4447 / \text { Geçici10) }\end{array}$ & Özel Sektör & $\begin{array}{l}48 \text { ay, } 36 \\
\text { ay, } 24 \text { ay, } 12 \\
\text { ay / } \\
31.12 .2020 \\
\end{array}$ & PEK & $\begin{array}{l}\text { MYÖ } \\
\text { İKMH;H;A } \\
\text { GSS }\end{array}$ & İşv. His. Tamamı & $\begin{array}{l}\text { İşs. Sig. } \\
\text { Fonu }\end{array}$ \\
\hline $\begin{array}{l}\text { İEP } \\
\text { (4447/Geçici15) }\end{array}$ & Özel Sektör & $\begin{array}{l}42 \text { ay, } 30 \\
\text { ay / } \\
31 / 12 / 2018\end{array}$ & $\begin{array}{l}\text { Önce } \\
\text { PEK } \\
\text { üzerinden } \\
\% 5 \\
\text { Kalan } \\
\text { PEK Alt } \\
\text { Sinırı } \\
\end{array}$ & $\begin{array}{l}\text { MYÖ } \\
\text { İKMH;H;A } \\
\text { GSS }\end{array}$ & İşv. His. Tamamı & $\begin{array}{l}\text { İşs. Sig. } \\
\text { Fonu }\end{array}$ \\
\hline \multirow{2}{*}{$\begin{array}{l}\text { İşveren Desteği } \\
\text { (4447/Geçici19) }\end{array}$} & $\begin{array}{l}\text { Özel Sektör / } \\
\text { İmalat ve } \\
\text { Bilișim }\end{array}$ & $\begin{array}{l}12 \text { ay, } 18 \\
\text { ay / } \\
31.12 .2020 \\
\end{array}$ & PEK & $\begin{array}{l}\text { MYÖ } \\
\text { İKMH;H;A } \\
\text { GSS }\end{array}$ & $\begin{array}{l}\text { İşv. His. Tamamı } \\
+ \\
\text { Sig. His. Tamamı }\end{array}$ & \multirow{2}{*}{$\begin{array}{l}\text { İşs. Sig. } \\
\text { Fonu }\end{array}$} \\
\hline & Özel Sektör & $\begin{array}{l}12 \text { ay / } \\
31.12 .2020\end{array}$ & $\begin{array}{l}\text { PEK Alt } \\
\text { Sinır }\end{array}$ & $\begin{array}{l}\text { MYÖ } \\
\text { İKMH;H;A } \\
\text { GSS } \\
\end{array}$ & $\begin{array}{l}\text { İşv. His. Tamamı } \\
+ \\
\text { Sig. His. Tamamı }\end{array}$ & \\
\hline $\begin{array}{l}\text { İşveren Desteği } \\
(4447 / \text { Geçici20) }\end{array}$ & $\begin{array}{l}\text { Özel Sektör/ } \\
\text { İmalatta ustalık } \\
\text { belgesi olan 1- } \\
3 \text { sigortalısı } \\
\text { olan }\end{array}$ & $\begin{array}{l}\text { Sürekli / } \\
31.12 .2020\end{array}$ & $\begin{array}{l}\text { PEK Alt } \\
\text { Sinırı }\end{array}$ & $\begin{array}{l}\text { MYÖ } \\
\text { İKMH;H;A } \\
\text { GSS }\end{array}$ & İşv. His. Tamamı & Hazine \\
\hline $\begin{array}{l}\text { İşveren Desteği } \\
(4447 / \text { Geçici21) }\end{array}$ & $\begin{array}{l}\text { Özel Sektör/ } \\
\text { Özel Sektör/ } \\
\text { İmalatta ustalık } \\
\text { belgesi olan 1- } \\
3 \text { sigortalıs1 } \\
\text { olan }\end{array}$ & $\begin{array}{l}12 \text { ay / } \\
31.12 .2020\end{array}$ & $\begin{array}{l}\text { PEK Alt } \\
\text { Sinır }\end{array}$ & $\begin{array}{l}\text { Gelir } \\
\text { vergisinden } \\
\text { terkin }\end{array}$ & - & Hazine \\
\hline $\begin{array}{l}\text { İSG Önlemlerini } \\
\text { Teşvik ( } 4447 \\
\text { Ek4) }\end{array}$ & $\overline{\text { Özel }}$ & $3 Y_{11}$ & PEK & $\begin{array}{l}\text { İşsizlik } \\
\text { Sigortası }\end{array}$ & İşv. His. \%1'i & $\begin{array}{l}\text { İşs. Sig. } \\
\text { Fonu }\end{array}$ \\
\hline
\end{tabular}

\section{Engelli Sigortalı İstihdamına Yönelik Teşvik (4857/30)}

Engellilerin çalışma hayatına kazandırılması için getirilen ve 01.07.2008 tarihinde uygulamaya konulan sürekli bir teşviktir. 4857 sayılı İş Kanununun 30. maddesine göre, özel sektöre ait kontenjan dahilindeki engellileri çalıştıran işyerleri ile korumalı işyerleri, kontenjan fazlası engelli sigortalı çalıştıran işyerleri ve yükümlü olmadığı halde engelli çalıştıran işyerlerinde sigortalıların, prime esas kazanç alt sınırı üzerinden hesaplanan sigorta primi işveren hisselerinin $(\% 20,5)$ tamamının Hazinece karşılanır (Alper, 2017, s.242). İşveren hissesine ait primlerin Hazinece karşılanabilmesi için işverenlerin çalıştırdıkları sigortalılarla ilgili olarak aylık prim ve hizmet belgelerinin yasal süresi içerisinde Sosyal Güvenlik Kurumuna verilmesi ve sigortalıların tamamina ait sigorta primlerinin sigortalı hissesine isabet eden tutarı ile Hazinece karşılanmayan işveren hissesine ait tutarın ödenmiş olması şarttır (Güzel vd, 2018, s. 306). 
5510 sayılı Kanunun 81. maddesinin 1. fıkrasının (1) bendi uyarınca, malullük, yaşlllık ve ölüm sigortası primlerinin işveren hissesinden uygulanacak 5 puanlık indirim için aranan "genel şartlar” bu teşvik için de geçerlidir.

Sosyal güvenlik destek primine tabi çalışanlar, topluluk sigortasına tabi çalışanlar, yurt dışında çalışan sigortalılar ile aday çırak, çırak ve öğrencilerden dolayı işverenler bu teşvikten yararlanamaz.

\section{Araştırma, Geliştirme ve Tasarım Faaliyetlerine iliş̧in Teşvik (5746/3)}

5746 sayılı Araştırma ve Geliştirme Faaliyetlerinin Desteklenmesi Hakkında Kanunda da sosyal sigorta primleri ile ilgili olarak bir teşvik yer almaktadır. 01.04.2008 başlayan bu teşvik ArGe/Tasarım ve destek personeli ile 4691 sayılı Kanununun geçici 2. maddesi uyarınca ücreti gelir vergisinden muaf olan personelin; ücretleri üzerinden hesaplanan sigorta primi işveren hissesinin (\%20,50) \%50'si_31.12.2023 tarihine kadar Maliye Bakanlığı (Hazine ve Maliye Bakanlığı) bütçesine konulacak ödenekten karşılanacaktır (Bozdemir, 2018, s.17; Çalışma Sosyal Güvenlik Bakanlığı, 2013, s.55).

$\mathrm{Bu}$ teşvikten yararlanabilmek için aylık prim ve hizmet belgesinin Kuruma yasal süresi içinde verilmiş olması, sigortalının fiilen çalışması, Ar-Ge/Tasarım personeli veya Ar-Ge personel sayısının \% 10’u aşılmamak kaydıyla destek personeli ya da 4691 sayılı Kanun uyarıca ücreti gelir vergisinden istisna tutulmuş personel olması gereklidir.

Bu teşvikle, 5510 sayılı Kanunun 81. maddesinin 1. fikrasının (1) bendi uyarınca, malullük, yaşlılık ve ölüm sigortası primlerinin işveren hissesinden uygulanacak 5 puanlık indirim birlikte uygulanacaksa önce 5 puanlık indirim uygulanacak ardından kalan \%15,5 işveren payının yarısı $(\% 7,75)$ sigorta primine esas kazanç üzerinden hesaplanacaktır (http://www.sgk.gov.tr/wps/portal/sgk/tr/calisan/isveren/ist-tesvikleri).

\section{Kültür Yatırımları ve Girişimleri Hakkında Uygulanan Sigorta Primi Teşviki (5225/5)}

01.08.2004 tarihinde başlayan ve prim teşviki öngören bir başka düzenleme de 5225 sayılı Kültür Yatırımları ve Girişimlerini Teşvik Kanununda yer almaktadır. Kültür Yatırım Belgesi almış olan işyerlerinde fiilen çalışan sigortalıların prime esas kazançları üzerinden hesaplanan sigorta primi işveren hissesinin (\%20,5) 3 yll boyunca \%50'si, Kültür Girişim Belgesi almış işyerlerinde fiilen çalışan sigortalıların ise prime esas kazançları üzerinden hesaplanan sigorta primi işveren hissesinin $(\% 20,5) 7$ yll boyunca \%25'i, Kültür ve Turizm Bakanlı̆̆ bütçesine konulan ödenekten karşılanacaktır. Sürekli bir teşviktir (Sözer, 2017, s.218; Çalışma Sosyal Güvenlik Bakanlığı, 2013, s.57). İşverenin, kurumlar vergisi mükellefi olması, Kültür Yatırım Belgesi veya Kültür Girişim Belgesi alınmış olması, aylık prim ve hizmet belgesi Kuruma yasal süresinde verilmiş olması, Türkiye genelinde prim, idari para cezası ve bunlara ilişkin gecikme zammı ve cezası borcu bulunmaması, varsa bu borçlar yapılandırılmış, taksitlendirilmiş ve düzenli ödeniyor olması gerekmektedir (Umdu ve Yıldız, 2010, s.161; Güzel vd. 2018, s.311). 
$\mathrm{Bu}$ teşvikle, 5510 sayılı Kanunun 81. maddesinin 1. fikrasının (1) bendi uyarınca, malullük, yaşlılık ve ölüm sigortası primlerinin işveren hissesinden uygulanacak 5 puanlık indirim birlikte uygulanacaksa önce 5 puanlık indirim uygulanacak ardından kalan ve kalan \%15,5 işveren payının 50'si veya \%25’i SPEK üzerinden hesaplanacaktır.

Tablo 3'de yukarıda ifade edilen 4857 sayılı İş Kanunu, 5746 sayılı Kanun ve 5225 sayılı Kanunda düzenlenen teşviklerin tablo haline getirilmiş özet bilgisi bulunmaktadır.

Tablo 3. 4857, 5764 ve 5225 sayılı Kanunlar kapsamındaki teşvikler

\begin{tabular}{|c|c|c|c|c|c|c|}
\hline Teşvik Türü & $\begin{array}{l}\text { Sektör / } \\
\text { Kapsam }\end{array}$ & $\begin{array}{l}\text { Teşvikin } \\
\text { süresi ve } \\
\text { Bitiş } \\
\text { Tarihi } \\
\end{array}$ & $\begin{array}{l}\text { Prim } \\
\text { Matrahı }\end{array}$ & $\begin{array}{l}\text { Sigorta } \\
\text { Kolu }\end{array}$ & $\begin{array}{l}\text { Teşvik } \\
\text { Oranı / } \\
\text { Miktar }\end{array}$ & $\begin{array}{l}\text { Finansman } \\
\text { Kay. }\end{array}$ \\
\hline $\begin{array}{l}\text { Engelli İstih. } \\
(4857 / 30)\end{array}$ & Özel Sektör & Sürekli / - & $\begin{array}{l}\text { PEK Alt } \\
\text { Sinırı }\end{array}$ & $\begin{array}{l}\text { MYÖ } \\
\text { IKMH;H;A } \\
\text { GSS } \\
\end{array}$ & $\begin{array}{l}\text { İşv. His. } \\
\text { Tamamı }\end{array}$ & Hazine \\
\hline $\begin{array}{l}\text { Ar-Ge Teşviki } \\
(5746 / 3)\end{array}$ & Özel Sektör & $\begin{array}{l}\text { Sürekli / } \\
31.12 .2023\end{array}$ & PEK & $\begin{array}{l}\text { MYÖ } \\
\text { İKMH;H;A } \\
\text { GSS }\end{array}$ & $\begin{array}{l}\text { İşv. His. } \\
\% 50 \text { 'si }\end{array}$ & $\begin{array}{l}\text { Maliye } \\
\text { Bakanlığı } \\
\text { (Hazine ve } \\
\text { Maliye } \\
\text { Bakanlığı) }\end{array}$ \\
\hline \multirow{2}{*}{$\begin{array}{l}\text { Kültür } \\
\text { Yatırımları } \\
(5225 / 5)\end{array}$} & $\begin{array}{l}\text { Özel Sektör / } \\
\text { Kültür Yatırım } \\
\text { Belgesi }\end{array}$ & $3 \mathrm{Y} 1 \mathrm{l} /-$ & PEK & $\begin{array}{l}\text { MYÖ } \\
\text { İKMH;H;A } \\
\text { GSS }\end{array}$ & $\begin{array}{l}\text { İşv. His. } \\
\% 50 \text { 'si }\end{array}$ & \multirow{2}{*}{$\begin{array}{l}\text { Kültür ve } \\
\text { Turizm } \\
\text { Bakanlığı }\end{array}$} \\
\hline & $\begin{array}{l}\text { Özel Sektör / } \\
\text { Kültür } \\
\text { GirişimBelgesi }\end{array}$ & $7 \mathrm{Y}_{11} / \mathrm{-}$ & PEK & $\begin{array}{l}\text { MYÖ } \\
\text { İKMH;H;A } \\
\text { GSS }\end{array}$ & $\begin{array}{l}\text { İşv. His. } \\
\% 25 \text { 'si }\end{array}$ & \\
\hline
\end{tabular}

\section{Sonuç}

İşverenler, genellikle 5510 sayılı Sosyal Sigortalar ve Genel Sağlık Sigortası Kanununun 81. maddesinin 1. fikrasının (1) bendinde düzenlenmiş olan malullük, yaşlılık ve ölüm sigortası primlerinin işveren hissesine uygulanacak 5 puanlık prim indiriminden yararlanıyor olsalar da son yıllarda 4447 sayılı İşsizlik Sigortası Kanunu, 4857 sayılı İş Kanunu, 5746 Araştırma ve Geliştirme Faaliyetlerinin Desteklenmesi Hakkındaki Kanunun, 5225 sayılı Kültür Yatırımları ve Girişimlerini Teşvik Kanunu ile ilave istihdamı artırılması, gençlerin, kadınların ve mesleki yeterlilik belgesi olanların ve engellilerin istihdama katılımının kolaylaştıran birçok indirim, teşvik ve destek uygulamaya konmuştur. Bütün bu teşvik uygulamaları incelendiğinde uygulamalar arasında bir standardın olmadığı, birçok farklılık bulunduğu tespit edilmiştir. $\mathrm{Bu}$ farklılıkların başında da teşvikin sağlanacağı kurum ve kaynağı gelmektedir.

Teşvik uygulamaları kapsamında birçok teşvik, destek ve indirim olduğu gibi bunlar için gerekli olan kaynakların kullanılacağı yerler ve kurumlar da bir o kadar çoktur. Örneğin, İşsizlik Sigortası Fonu, Hazine, Maliye Bakanlığı (Hazine ve Maliye Bakanlığı), Ekonomi Bakanlığı (Sanayi ve Teknoloji Bakanlığı) ve Kültür ve Turizm Bakanlığı gibi birçok yerden bu teşvikler finanse edilmektedir. Bu durum sistemin anlaşılmasını ve kavranmasını güçleştirmektedir. Bu nedenle teşviklerin aynı kaynaktan yapılarak karmaşıklığın giderilmesi ve biraz daha sadeleștirilmesi gerekmektedir. 
Aynı şekilde bazı teşvikler sigortalının prime esas kazancı (PEK) üzerinden bazıları ise prime esas kazanç alt sınırı (PEK Alt Sınır) üzerinden alınmaktadır. Teşviklerde iki ayrı kazanç miktarının esas alınması konuyu daha karmaşık hale getirmektedir. Bu konuda da bir örneklik sağlanması yararlı olacaktır.

Ayrıca, bazı teşvikler sadece işveren prim payı üzerinden verilirken bazı teşvikler de ise hem işveren hem de sigortalı prim payının toplamı üzerinden sağlanmaktadır. Bu durum da karışıklıklara yol açmakta ve sistemin anlaşılmasını ve uygulanmasını güçleştirmektedir. $\mathrm{Bu}$ konuda da bir örneklik sağlanması yararlı olacaktır.

Bunların haricinde de teşvik uygulamalarında bazı sorunlar göze çarpmaktadır. 5510 sayılı Kanunun 81. maddesinin 1. fikrasının (1) bendinde düzenlenmiş 5 puanlık indirimde, eğer $o$ işyerinde alt işveren çalış̧ırılıyor ise alt işverenin çalıştırdığı sigortalıların SGK'ya bildirilmediğinin tespit edilmesi halinde, hem kayıt dışı sigortalı çalıştıran alt işverene hem de asıl işverene müeyyide uygulanmaktadır. Asıl işverene müeyyide uygulanarak indirimden yararlandırılmaması kanımızca pek adil değildir. Bu hususun da yeniden gözden geçirilmesinde yarar vardır.

Ayrıca, alt işverenin SGK'ya olan borçlarından dolayı asıl işvereni sorumlu tutarak sigorta primi, işsizlik sigortası primi veya idari para cezası bulunması nedeniyle asıl işvereni 5 puanlık prim indiriminden mahrum bırakmak da adil değildir. Bu konunun da yeniden gözden geçirilmesi gerekmektedir.

5510 sayılı Kanunun 81. maddesinin 1. fikrasının (1) bendinde düzenlenmiş olan 5 puanlık indirimle ilgili bir diğer sorun da şöyledir. 5510 sayılı Kanunun Ek 14. maddesinin 1. fikrasıyla, "mahkeme kararıyla veya yapılan kontrol ve denetimlerde çalıştırdığı kişileri sigortalı olarak bildirmediği veya bildirilen sigortalıyı fiilen çalışırmadığı tespit edilen işyerleri ilk tespitte bir ay süreyle, ilk tespit tarihinden itibaren üç yl içinde tekrar eden her bir tespit için ise bir yil süreyle bu Kanun, 3294 sayılı Sosyal Yardımlaşma ve Dayanışmayı Teşvik Kanunu ve 4447 sayılı İssizilik Sigortası Kanununda yer alan sigorta primi teşvik, destek ve indirimlerden yararlanamaz." hükmü getirilmiştir. Ancak, anılan maddenin 3. fikrasında eğer bir işyerinde beş kişiden fazla olmamak koşuluyla çalıştırılan toplam sigortalı sayısının \%1'ini aşmamak kaydıyla, çalıştırılanların sigortalı olarak bildirilmediğinin veya bildirilen kişilerin fiilen çalışmadığının (sahte sigortalılık) tespit edilmesi hâlinde, 5510 sayılı Kanunun ek 14. maddesinin 1. fikrasındaki müeyyidenin uygulanmayacağı belirtilmektedir. Bu durum da kayıt dışılığı artırabileceği için yeniden değerlendirilmelidir.

SGK'ya prim ödeme gün sayısı veya prime esas kazanç tutarının eksik bildirdiğinin tespit edildiği durumlar da teşvikle ilgili sorunlu alanlar arasındadır. Prim ödeme gün sayısı veya prime esas kazanç tutarının eksik bildirdiğinin tespit edilmesi halinde işverenler, kanunlarda öngörülen diğer şartları sağlamaları kaydıyla 5 puanlık prim indirimden yararlanmaya devam etmektedirler. $\mathrm{Bu}$ da adil olmadığı gibi suistimale açık bir konu olup yeniden düzenlenmelidir. 
İlave 6 puan indiriminde yararlanabilmek için işyerinde ilgili ayda 10 ve üzerinde sigortalı çalıştırma şartı bulunmaktaydı. Bu koşul 2016/Mart ayından itibaren kaldırılmıştır. Daha fazla işverenin bu indirimden yararlanmasını sağlaması bakımından bu düzenlemenin isabetli olduğunu belirtmek gerekir.

Son olarak iş kazası meydana gelmeyen işyerlerinde çalışanların işsizlik sigortası işveren prim payı teşvik olarak bir sonraki takvim yılından geçerli olmak üzere ve üç yıl süreyle \%1 olarak alınmaktadır. Aslında iş kazası meydana gelmeyen işyerlerinde indirimin iş kazası ve meslek hastalıkları sigortası priminden yapılması gerekmektedir. Ancak teşvikin neden işsizlik sigortası işveren priminden yapıldığı anlaşılamamaktadır. Bu hususun da yeniden gözden geçirilmesinin sistemin tutarlı olması bakımından önemli olduğu kanaatindeyiz.

\section{Kaynakça}

Alper, Y. (2018). Türk Sosyal Güvenlik Sistemi ve Sosyal Sigortalar Hukuku Dersleri. Bursa: Dora.

Başbuğ, A. (2103). Türk Sosyal Güvenlik Sisteminde Sosyal Sigortalar. Ankara: Şeker-İş

Bozdemir, E. (2018). Ar-Ge ve Yenilik Faaliyetlerinde Teşviklerin Muhasebe Standartları Açısından Değerlendirilmesi ve Muhasebeleştirilmesi. Mali Çözüm. Ocak-Şubat 2018, 13 40.

Caniklioğlu, N. (2011). Sosyal Sigortalarda Prim Teşvikleri. İstanbul: Beta.

Gerek, N., Oral, A. İ. (2019), Sosyal Güvenlik Hukuku. Eskişehir: Anadolu Üniversitesi.

Gündüz, T. (2018). 7103 Sayılı Yasa Ile Getirilen Sigorta Primi, Ücret ve Vergi Teşviki. Mali Çözüm, Mayıs-Haziran 2018, 227-238.

Güzel, A., Okur, A. R., Caniklioğlu, N. (2018). Sosyal Güvenlik Hukuku. İstanbul: Beta.

Olgaç C., Bulut, M. (2012). Sosyal Güvenlik Uygulamaları İşveren Rehberi. Ankara: TİSK.

Sözer, A. N., (2017). Türk Sosyal Sigortalar Hukuku. İstanbul : Beta

Tuncay, C., Ekmekçi, Ö., (2017). Sosyal Güvenlik Hukuku Dersleri. İstanbul: Beta.

Umdu, E., Yıldız, R. (2010). Sigorta Prim Teşvikleri ve İş̧̧i Ödenekleri. İstanbul: İTO.

Yetik, M. (2018). Sosyal Güvenlik Hukukunda Primler ve Prim Teşvikleri. İstanbul: Legal.

Ünlü, K. (2018). 2018 Yılında Uygulanacak Yeni İşveren Desteği. Mali Çözüm, Mayıs-Haziran $2018,239-244$.

Doğan, N. http://www.hurriyet.com.tr/ik-yeni-ekonomi/2019un-istihdam-tesvikleri410734336 (25.01.2018).

Özcan, C. https://www.dunya.com/kose-yazisi/yeni-istihdama-2020-yilina-kadar-prim-gelirvergisi-ve-damga-vergisi-tesviki/401933 (26.01.2018). 
Çalışma Sosyal Güvenlik Bakanlığı (2013). Sosyal Güvenlik Kurumu, Sosyal Güvenlik Sisteminde Primler, SGK Yayın No:70, Sosyal Güvenlik Bilgi Serisi: 2013/3. (Çalışma Sosyal Güvenlik Bakanlı̆̆ı).

Sosyal Güvenlik Kurumu Başkanlığı. (2013). Sosyal Güvenlik Kapsamındaki Sigortalıların Hak ve Yükümlülükleri. Ankara. (SGK Başkanlığı).

http://iskanunu.com/kanun-ve-yonetmelikler/son-degisiklikler/2018-torba-yasa-tesvikleri/ (14.02.2018).

http://istihdamatesvik.com/teşvikler (25.01.2018).

http://www.muhasebetr.com/yazarlarimiz/kenanozdemir/001/ (25.01.2018).

http://www.sgk.gov.tr/ İstihdam Teşvikleri Hakkında Bilinmesi Gerekenler (25.01.2018).

http://www.sgk.gov.tr/wps/portal/sgk/tr/calisan/isveren/ist-tesvikleri (18.10.2019). 